JPPMS, Vol. 5, No. 1, 2021

Jurnal Penelitian Pendidikan Matematika dan Sains

http://journal.unesa.ac.id/index.php/jppms/

\title{
PROFIL METAKOGNISI SISWA SMA DALAM MENYELESAIKAN SOAL CERITA PADA MATERI SISTEM PERSAMAAN LINEAR TIGA VARIABEL DITINJAU DARI KEMAMPUAN MATEMATIKA
}

\author{
Oleh: \\ Anggun Vita Loka ${ }^{1}$, Rini Setianingsih ${ }^{2}$ \\ 1,2Jurusan Matematika FMIPA Universitas Negeri Surabaya \\ 1anggunloka16030174026@mhs.unesa.ac.id \\ 2rinisetianingsih@unesa.ac.id
}

\begin{abstract}
Abstrak - Metakognisi dapat membantu siswa untuk meningkatkan keterampilan berpikirnya. Hal ini dikarenakan siswa sadar terhadap proses berpikirnya sendiri dan siswa dapat mengevaluasi hasil dari proses berpikirnya. Sehingga siswa dapat memperkecil kesalahan dalam menyelesaikan suatu masalah serta dapat mengatur rencana yang tepat dalam menyelesaikan suatu masalah. Dengan demikian siswa yang melibatkan metakognisinya dalam menyelesaikan suatu masalah akan jauh lebih baik proses belajarnya. Tujuan penelitian ini untuk mendeskripsikan profil metakognisi siswa SMA dalam menyelesaikan soal cerita pada materi sistem persamaan linear tiga variabel dengan kemampuan matematika tinggi, sedang dan rendah. Penelitian ini adalah penelitian deskriptif kualitatif yang dilaksanakan pada kelas XI SMAN 1 Kota Probolinggo tahun ajaran 2020/2021. Subjek yang dipilih yaitu satu subjek yang masing-masing mewakili kemampuan matematika tinggi, sedang dan rendah. Cara memilih seorang subjek yang mewakili satu kemampuan matematika tinggi, sedang dan rendah yaitu subjek yang memiliki dominan pada kemampuan matematika tersebut. Instrumen penelitian terdiri dari tes kemampuan matematika, tes soal cerita dan pedoman wawancara. Hasil penelitian menunjukkan bahwa subjek dengan kemampuan matematika tinggi dalam memahami soal cerita dapat melaksanakan aktivitas metakognisi merencanakan (planning), memantau (monitoring), dan mengevaluasi (evaluating) pada tahap memahami masalah, membuat rencana pemecahan masalah, melaksanakan rencana pemecahan masalah dan memeriksa kembali hasil yang diperoleh. Subjek dengan kemampuan matematika sedang dan rendah dalam memahami soal cerita dapat melaksanakan aktivitas metakognisi merencanakan (planning), memantau (monitoring), dan mengevaluasi (evaluating) pada tahap memahami masalah, membuat rencana pemecahan masalah, melaksanakan rencana pemecahan masalah namun tidak pada tahap memeriksa kembali hasil yang diperoleh.
\end{abstract}

Kata kunci: Metakognisi, Soal Cerita, Sistem Persamaan Linear Tiga Variabel, Kemampuan Matematika.

\begin{abstract}
Metacognition can help students improve their thinking skills. This is because students are aware of their own thinking processes and students can evaluate the results of their thinking processes. So that students can minimize errors in solving a problem and can set the right plan in solving a problem. Thus students who involve their metacognition in solving a problem will have a much better learning process. The purpose of this study was to describe the metacognition profile of high school students in solving story problems on three-variable linear equation system material with high, medium and low math abilities. This research is a qualitative descriptive study conducted in class XI of SMAN 1 Kota Probolinggo in the academic year 2020/2021. The selected subject is one subject, each of which represents high, medium and low math abilities. How to choose a subject that represents a high, medium and low math ability, that is, a subject that has dominance in that math ability. The research instrument consisted of a math ability test, a story question test and an interview guide. The results showed that subjects with high mathematical skills in understanding story problems could carry out planning, monitoring, and evaluating activities at the stage of understanding the problem, making problem-solving plans, implementing problem-solving plans and reexamining the results. which is obtained. Subjects with moderate and low mathematical skills in understanding story problems can carry out planning, monitoring, and evaluating activities at the stage of understanding the problem, making problem-solving plans, implementing problem-solving plans but not at the re-checking stage. the results obtained.
\end{abstract}

Keywords: Metacognition, Story Questions, Three Variable Linear Equation Systems, Mathematics Ability. 


\section{Pendahuluan}

Kurikulum 2013 merupakan pengembangan dari kurikulum berbasis kompetensi, kurikulum 2004 dan kurikulum tingkat satuan pendidikan (KTSP) 2006 yang mengintegrasikan pengetahuan, keterampilan dan sikap (Kemendikbud, 2013). Dalam Kurikulum 2013 terdapat empat elemen perubahan, yakni standar kelulusan, standar isi, standar proses, standar penilaian (Kemendikbud, 2013). Standar kelulusan untuk ranah pengetahuan pada tingkat SMA meliputi pengetahuan faktual, konseptual, prosedural, dan metakognitif (Kemendikbud, 2013). Pengetahuan metakognitif menjadi standar kelulusan bagi siswa SMA agar siswa tersebut dapat menyadari kekurangan maupun kelebihan kemampuan berpikirnya.

Kurikulum 2013 juga menjelaskan bahwa salah satu tujuan pembelajaran matematika yaitu siswa dapat memecahkan masalah matematika yang mencakup kemampuan memahami masalah, membangun model matematika, menyelesaikan model matematika serta menerangkan penyelesaian yang diperoleh. Berdasarkan tujuan pembelajaran matematika tersebut dapat dinyatakan bahwa kemampuan memecahkan masalah menjadi salah satu bagian penting dalam pembelajaran matematika.

Kemampuan memecahkan masalah matematika saling berkaitan dengan pengetahuan akan masalah tersebut serta proses yang digunakan untuk menyelesaikannya (Laurens, 2006). Pemecahan masalah matematika dapat membantu siswa memiliki kesadaran berpikir tentang apa yang dipikirkannya dan membangun kemampuan dalam mengontrol proses berpikirnya. Kesadaran seseorang terhadap proses berpikirnya sendiri disebut sebagai metakognisi (Pratiwi, 2014).

Metakognisi merupakan istilah yang diperkenalkan oleh Flavell pada tahun 1976, yang menjelaskan bahwa "Metacognition is the knowledge and awareness of one's cognitive processes and the ability to monitor, regulate and evaluate one's thinking”. Metakognisi adalah pengetahuan, kesadaran proses kognitif dari seseorang juga keterampilan mengontrol, menyusun serta menilai pemikiran seseorang. Menurut Flavell (dalam Livingstone, 1997) metakognisi melibatkan dua komponen yaitu pengetahuan metakognitif (metacognitive knowledge) dan pengalaman atau regulasi metakognitif (metacognitive experiences or regulation). Pengetahuan metakognitif berkaitan dengan pengetahuan tentang proses kognitif dan pengetahuan yang dapat digunakan untuk memantau proses kognitif sedangkan pengalaman metakognitif adalah proses yang dapat digunakan untuk memantau aktivitas kognitif sehingga dapat mencapai tujuan kognitif.

Selain itu Livingstone (1997) menjelaskan metakognisi sebagaimana "Thinking about thinking" yaitu berpikir tentang berpikir. Metakognisi adalah berpikir tentang proses berpikir yang terjadi pada diri sendiri. Sedangkan Wellman (1985) menjelaskan bahwa "Metacognition is a form of cognition, a second or higher order thinking process which involves active control overcognitive processes. It can be simply defined as thinking about thinking or as a "person's cognition about cognition". Metakognisi adalah proses berpikir tingkat tinggi yang mengaitkan pengelolaan terhadap aktivitas kognitif. Sehingga metakognisi dapat dinyatakan sebagai berpikir seseorang mengenai proses berpikirnya sendiri serta pengendalian diri seseorang selama proses berpikir.

Berdasarkan uraian tersebut dapat disimpulkan bahwa metakognisi adalah pengetahuan dan kesadaran seseorang terhadap proses berpikirnya sendiri serta pengendalian diri seseorang yang terjadi selama proses berpikir. Metakognisi terdiri dari dua komponen, yaitu pengetahuan metakognitif dan pengalaman atau regulasi metakognitif. Pengetahuan metakognitif merupakan pengetahuan mengenai proses kognitif dan pengetahuan yang dapat digunakan untuk mengontrol proses kognitif sedangkan pengalaman metakognitif merupakan proses yang dapat digunakan untuk mengontrol aktivitas kognitif sehingga dapat mencapai tujuan kognitif.

Metakognisi dapat membantu siswa memiliki proses belajar yang baik khususnya pemecahan masalah matematika. Hal ini dikarenakan siswa sadar terhadap proses berpikirnya sendiri serta siswa dapat mengevaluasi hasil dari proses berpikirnya. Sehingga siswa dapat memperkecil kesalahan dalam menyelesaikan masalah serta dapat mengatur rencana yang tepat untuk bisa menyelesaikan masalah.

Sebelum siswa menyelesaikan suatu pemecahan masalah sebaiknya siswa diberi latihan untuk menyelesaikan soal cerita agar mampu memahami makna soal dan bagaimana menyusun strategi yang tepat dalam menyelesaikan soal. Sesuai hasil penelitian dari (Widhiastuti, 2014) yang menyatakan bahwa kebanyakan siswa kesulitan dalam menyelesaikan soal cerita yaitu dalam mengetahui makna soal cerita, apa yang ditanyakan dari soal cerita dan membuat model matematikanya.

Dalam penyelesaian soal cerita siswa memerlukan rencana yang tepat agar soal dapat terselesaikan dengan baik. Rencana yang 
digunakan dalam menyelesaikan soal antara siswa tidaklah sama. Salah satu kemungkinan penyebabnya yaitu kemampuan matematika. Sesuai hasil penelitian dari Farista (2011) yang mengungkapkan bahwa siswa yang berkemampuan matematika tinggi sanggup memahami permasalahan dengan baik, mampu menyusun rencana yang tepat, rencana yang digunakan dalam menyelesaikan masalah benar dan dapat memeriksa kembali hasil yang diperoleh, sedangkan siswa yang berkemampuan matematika sedang dan rendah memiliki kemungkinan tidak dapat menyusun rencana pemecahan masalah seperti yang dikerjakan oleh siswa yang berkemampuan matematika tinggi.

Kemampuan matematika siswa berpengaruh terhadap metakognisi yang terjadi selama proses penyelesaian soal cerita sesuai hasil penelitian dari (Fitriyah, 2014) yang menyatakan bahwa siswasiswi yang berkemampuan matematika tinggi serta siswa yang berkemampuan matematika sedang dapat melibatkan metakognisinya dengan baik dalam menyelesaikan soal cerita. Hal ini dikarenakan siswa tersebut mampu melakukan setiap kegiatan aktivitas metakognisi dengan baik yang meliputi planning, monitoring dan evaluating pada setiap tahap memahami soal, membuat model matematika dan menyelesaikan model matematika

Siswa-siswi yang berkemampuan matematika rendah serta siswi yang berkemampuan matematika sedang tidak dapat melibatkan metakognisinya dengan baik dalam menyelesaikan soal cerita. Hal ini dikarenakan siswa tersebut tidak dapat menyelesaikan soal cerita yang diberikan lupa cara menggunakan rumus SPLDV, kurangnya waktu pengerjaan, dan kurangnya persiapan belajar. Dalam penelitian ini menerangkan bahwa kemampuan matematika berpengaruh terhadap proses penyelesaian soal cerita sehingga dapat diketahui jika siswa tersebut telah melibatkan atau tidak melibatkan metakognisinya.

Adapun materi SPLTV dipilih karena materinya luas, aplikasinya dalam kehidupan sehari-hari cukup banyak serta dalam proses penyelesaiannya dapat menggunakan berbagai cara yang tersedia sehingga dapat mendorong siswa untuk melibatkan metakognisinya. Sesuai hasil penelitian dari (Siagin, 2016) yang menerangkan bahwa masalah matematika pada materi SPLTV dapat mendorong siswa melibatkan metakognisinya dengan baik dan tergolong tinggi yaitu sebesar $63 \%$ yang terbagi dalam empat tahap yaitu tahap memahami masalah dengan presentase sebesar $79 \%$, tahap merenanakan masalah dengan presentase sebesar 67\%, tahap melaksanakan rencana pemecahan masalah dengan presentase sebesar 57\%, serta pada tahap memeriksa kembali hasil yag diperoleh dengan presentase sebesar $48 \%$.

Berdasarkan uraian tersebut dapat disimpulkan bahwa metakognisi dapat membantu siswa untuk meningkatkan keterampilan berpikirnya dan SPLTV merupakan materi di SMA yang dapat mendorong siswa untuk melibatkan metakognisinya. Sehingga peneliti melaksanakan penelitian dengan judul "Profil Metakognisi Siswa SMA dalam menyelesaikan Soal Cerita pada Materi Sistem Persamaan Linear Tiga Variabel Ditinjau dari Kemampuan Matematika". Penelitian ini relevan dengan penelitian dari Pratiwi (2014) yang meneliti tentang "Profil Metakognisi Siswa SMP Dalam Memecahkan Masalah Matematika Ditinjau Dari Kemampuan Matematika Siswa." Kaitan penelitian pratiwi dan penelitian ini terletak pada profil metakognisi dan tinjauan yang digunakan yaitu ditinjau dari kemampuan matematika sedangkan untuk perbedaannya terletak pada penelitian dan tinjauan pemilihan subjek yang digunakan pada penelitian pratiwi digunakan subjek siswa SMP sedangkan pada penelitian ini digunakan subjek siswa SMA. Penelitian ini juga relevan dengan penelitian dari Fitriyah (2014) yang meneliti tentang "Metakognisi Siswa SMP Dalam Menyelesaikan Soal Cerita Ditinjau Dari Kemampuan Matematika Dan Gender." Kaitan penelitian Fitriyah dan penelitian ini terletak pada metakognisi siswa dalam menyelesaikan soal cerita sedangkan untuk perbedaannya terletak pada penelitian dan tinjauan pemilihan subjek pada penelitian fitriyah yang dideskripsikan adalah data tentang proses metakognisi dari siswa sedangkan dalam penelitian ini data tentang profil metakognisi dari siswa. Untuk tinjauan pemilihan subjek yang digunakan pada penelitian fitriyah digunakan subjek siswa SMP dengan tinjauan perbedaan kemampuan matematika dan gender sedangkan pada penelitian ini digunakan subjek siswa SMA dengan tinjauan kemampuan matematika.

\section{Metode}

Penelitian ini termasuk penelitian deskriptif kualitatif. Penelitian deskriptif kualitatif dirancang untuk memahami dan menggambarkan suatu fenomena yang dialami dengan cara mendeskripsikan profil metakognisi yang terjadi kepada siswa selama proses menyelesaikan soal cerita.

Sumber data penelitian ini yaitu siswa SMA kelas XI MIPA A sebanyak 16 siswa di SMAN 1 Kota Probolinggo. Instrumen dalam penelitian ini meliputi tes kemampuan matematika, tes soal cerita, dan pedoman wawancara. Setelah siswa 
diberikan tes kemampuan matematika hasil tes tersebut dianalisis berdasarkan pedoman penilaian dari Ratumanan \& Laurent (2011). Skor yang didapatkan siswa dari hasil tes tersebut digunakan untuk menggolongkan siswa ke dalam kategori kemampuan matematika tinggi, sedang dan rendah dengan ketentuan pada Tabel 1 berikut ini.

Tabel 1. Kategori Kemampuan Matematika

\begin{tabular}{|c|c|}
\hline Skor & Kemampuan Matematika \\
\hline $0-75$ & Rendah \\
\hline $75-85$ & Sedang \\
\hline $85-100$ & Tinggi \\
\hline
\end{tabular}

Pemilihan subjek dilihat dari nilai tes kemampuan matematika yang dominan mewakili satu kemampuan matematika tersebut. Selanjutnya memberikan tes soal cerita kepada subjek yang terpilih untuk mengetahui strategi yang digunakan oleh subjek dalam mengerjakan soal cerita. Data hasil tes soal cerita dianalisis dengan menyesuaikan jawaban subjek berdasarkan indikator metakognisi dalam memecahkan masalah matematika yang dikembangkan oleh Sumawan (2012) Kemudian dilakukan wawancara kepada tiga subjek yang terpilih untuk memperoleh informasi mendalam mengenai metakognisi yang tidak diperoleh melalui tes soal cerita.

\section{Hasil dan Pembahasan}

Siswa yang berkemampuan matematika tinggi (INTN) dapat memahami soal dengan baik ia membaca soal yang diberikan kemudia ia berpikir untuk mencari apa yang dimaksud dari soal dan ia juga berpikir bahwa soal yang diberikan dapat diselesaikan dengan rumus SPLTV yang pernah didapat pada kelas X. Selanjutnya INTN memiliki kesadaran untuk menuliskan apa yang diketahui dan apa yang ditanyakan soal. Ia melakukan hal tersebut karena kebiasaan yang selalu diajarkan oleh gurunya untuk mempermudah pengerjaan soal. Selain itu INTN juga yakin jika tidak memiliki kendala saat memahami soal cerita SPLTV yang diberikan. Dalam membuat rencana penyelesaian soal INTN mengubah data yang ada pada soal agar mudah diselesaikan dengan menggunakan rumus substitusi dan eliminasi dengan cara dimisalkan. INTN yakin jika rencana penyelesaiannya ini sudah benar dan tidak ada kesalahan. Setelah itu INTN mulai mengerjakan soal untuk mencari jawaban dan dalam proses pengerjaan ia tidak mengalami kesulitan serta INTN juga yakin jika jawaban yang ia peroleh sudah tepat. Selanjutnya sebelum mengakhiri penyelesaian INTN memiliki kesadaran berpikir un tuk memeriksa kebenaran dari proses pengerjaaan soal yang telah ia lakukan dan INTN juga yakin jika pembuktian yang ia lakukan telah benar sesuai dengan data yang ada pada soal. Sehingga INTN dapat dikatakan telah melibatkan metakognisinya dengan baik.
Siswa yang berkemampuan matematika sedang (SAFA) juga dapat memahami soal dengan baik ia membaca soal yang diberikan kemudia ia berpikir untuk mencari apa yang dimaksud dari soal dan ia juga berpikir bahwa soal yang diberikan dapat diselesaikan dengan rumus SPLTV. Selanjutnya SAFA memiliki kesadaran untuk menuliskan apa yang diketahui dan apa yang ditanyakan soal. Ia melakukan hal tersebut karena untuk mempermudah dalam pengerjaan soal. Selain itu SAFA juga yakin jika tidak memiliki kendala saat memahami soal cerita SPLTV yang diberikan. Dalam membuat rencana penyelesaian soal SAFA mengubah data yang ada pada soal agar mudah diselesaikan dengan menggunakan rumus substitusi dan eliminasi. SAFA yakin jika rencana penyelesaiannya ini sudah benar dan tidak ada kesalahan. Setelah itu SAFA mulai mengerjakan soal untuk mencari jawaban dan dalam proses pengerjaan ia tidak mengalami kesulitan serta SAFA juga yakin jika jawaban yang ia peroleh sudah tepat. Dalam hal ini SAFA lupa untuk melakukan pemeriksaan kembali terhadap hasil yang telah diperoleh. Ia tidak melakukan pembuktian pada soal yang telah ia kerjakan sehingga SAFA belum melibatkan metakognisinya dengan baik. Hal ini sesuai dengan hasil penelitian Wahyuningtyas (2019) yang menyatakan bahwa siswa laki-laki atau perempuan yang berkemampuan matematika sedang mampu melakukan kegiatan perencanaan dan pemantauan tetapi kurang lengkap karena beberapa indikator tidak tercapai salah satunya yaitu tidak mampu menguji hasil yang diperoleh namun melakukan kegiatan evaluasi dengan lengkap.

Siswa yang berkemampuan matematika rendah (KART) dapat memahami soal dengan baik ia membaca soal yang diberikan kemudian ia berpikir untuk mencari apa yang dimaksud dari soal dan ia juga berpikir bahwa soal yang diberikan dapat diselesaikan dengan rumus SPLTV. Selanjutnya KART memiliki kesadaran untuk menuliskan apa yang diketahui dan apa yang ditanyakan soal. Ia melakukan hal tersebut karena untuk mempermudah dalam pengerjaan soal. Selain itu KART juga yakin jika tidak memiliki kendala 
saat memahami soal cerita SPLTV yang diberikan. Dalam membuat rencana penyelesaian soal KART mengubah data yang ada pada soal agar mudah diselesaikan dengan menggunakan rumus substitusi dan eliminasi. KART yakin jika rencana penyelesaiannya ini sudah benar dan tidak ada kesalahan. Setelah itu KART mulai mengerjakan soal untuk mencari jawaban dan dalam proses pengerjaan ia tidak mengalami kesulitan serta KART juga yakin jika jawaban yang ia peroleh sudah tepat. Dalam hal ini KART tidak melakukan pengecekan kembali terhadap hasil yang telah diperoleh. Ia tidak melakukan pembuktian pada soal yang telah ia kerjakan sehingga KART belum melibatkan metakognisinya dengan baik. Hal ini sesuai dengan hasil penelitian dari Qomariyah (2020) yang menyatakan bahwa siswa dengan kemampuan matematika rendah tidak mampu melakukan aktivitas metakognisi yang meliputi perencanaan, pemantauan dan evaluasi pada tahap memeriksa kembali hasil yang diperoleh.

\section{Simpulan}

Siswa yang berkemampuan matematika tinggi (INTN) dapat melibatkan metakognisinya dengan baik ia memiliki kesadaran untuk teliti dalam mengerjakan soal. INTN memiliki pengetahuan yang cukup banyak mengenai soal yang diberikan hal ini menjadikan INTN tahu apa yang harus dan tidak ia lakukan agar mendapatkan hasil yang diperoleh dengan tepat. Ia juga melakukan pengecekan kembali terhadap jawaban yang diperoleh.

Siswa yang berkemampuan matematika sedang (SAFA) dan Siswa yang berkemampuan matematika rendah (KART) masih belum dapat melibatkan metakognisinya dengan baik hal ini dikarenakan SAFA dan KART kurang teliti dalam pengerjaan soal cerita yang diberikan mereka tidak melakukan pembuktian hasil yang diperoleh pada saat mengerjakan soal cerita.

\section{Saran}

Metakognisi membuat siswa memiliki proses belajar yang baik dengan metakognisi siswa mampu menuntun dirinya untuk mengerjakan sesuatu yang bermanfaat ataupun tidak bermanfaat bagi proses belajarnya dalam hal ini peneliti mempunyai saran untuk guru karena tidak semua siswa mengetahui kekurangan maupun kelebihan dari kemampuan berpikirnya. Guru dapat membantu siswa untuk melibatkan metakognisinya dengan cara menyuruh siswanya untuk melakukan perenungan diri agar siswa dapat menyadari kesalahan belajarnya serta guru dapat memberi siswa sanksi berupa memotong nilai agar siswa tidak terbiasa dengan kesalahan yang telah dilakukan.

\section{Daftar Pustaka}

Farista, R. D. 2011. Kemampuan Matematika Siswa dalam Memecahkan Masalah Kontekstual Matematika pada Materi Lingkaran di Kelas VIII SMP Negeri 1 Dawar Blandong Mojokerto. Skripsi. Tida dipublikasikan. Surabaya: Universitas Negeri Surabaya.

Flavell, J.H. 1976. Metacognitive Aspects of Problem Solving. (Ed) The nature of intelligence. Hillsdale, New Jersey: Earlbaum Associates Inc. (Online), (http://tip.Psychology.org/meta.html) (diakses tanggal 20 November 2019).

Fitriyah, I., dan Setianingsih. R. 2014. “ Metakognisi Siswa SMP dalam Menyelesaikan Soal Cerita Ditinjau dari Kemampuan Matematika Siswa dan Gender". Jurnal Penelitian Pendidikan matematika. Vol. 3 (3): hal. $122-123$.

Laurens, T. 2006. "Kumpulan Makalah Lengkap Pembicara Utama dan Kumpulan Abstrak Para Peserta Konferensi Nasional Matematika XIII dan Kongres Himpunan Matematika Indonesia: Pengembangan Metakognisi Siswa dalam Pemecahan Masalah Matematika". Semarang: Jurusan Matematika FMIPA Universitas Negeri Semarang.

Livingston, J.A. 1997. Metacognitive An overview. (Online) http://www.gse.buffalo.edu/fas/shuell/CEP56 4/Metacog.html. (diakses tanggal 20 November 2019).

Permendikbud. 2013. Kerangka Dasar dan Struktur Kurikulum Sekolah Menengah Atas/ Madrasah Aliyah. Jakarta: Kemendikbud.

Permendikbud. 2016. Kerangka Dasar dan Struktur Kurikulum Sekolah Menengah Atas/ Madrasah Aliyah. Jakarta: Kemendikbud.

Pratiwi, S.D. 2014. Profil Metakognisi Siswa SMP dalam Memecahkan Masalah Matematika Ditinjau dari Kemampuan Matematika Siswa. Skripsi tidak diterbitkan. Surabaya: Universitas Negeri

Qomariyah, F. 2020. Profil Metakognisi Siswa dalam Memecahkan Masalah Matematika Ditinjau dari Kemampuan Matematika Siswa. Skripsi. Surabaya: UIN Sunan Ampel Surabaya.

Siagin dkk. 2016. "Metakognisi Siswa Dalam Menyelesaikan Masalah Sistem Persamaan Linear Tiga Variabel Di Sekolah Menengah 
Atas". Pontianak: Jurnal Pendidikan Matematika FKIP untan Vol 5 No 6.

Wahyuningtyas, A.D. 2019. Profil Metakognisi dalam Menyelesaikan Soal Cerita Materi Sistem Persamaan Linear Dua Variabel Ditinjau dari Kemampuan Matematika dan Gender. Skripsi. Jember: Universitas Jember.

Wellman, H., 1985. The Origins of Metacognition. In D.L.Forrest-Pressley, G.E.MacKinnon, and T.G Waller (eds.), Metacognition, Cognition, and Human Performance, volume 1 Theoretical Perspectives, chapter 1. Academic Press, Inc.

Widhiastuti, T.H. 2014. Analisis Kesalahan Siswa menyelesaikan Soal Uraian Matematika Berbentuk Cerita Pokok Bahasan Sistem Persamaan Linier Dua Variabel pada Siswa Kelas VIII SMP Negeri 2 Ngemplak Boyolali. Skripsi. Surakarta: Universitas Muhamadiyah Surakarta. 